\title{
Agronomic performance of canola submitted to desiccation with herbicides at different maturation stages
}

\author{
Willian B. Rosa ${ }^{1}$, José B. Duarte Júnior ${ }^{1}$, Ivonei Perego ${ }^{1}$, Bruno H. de Almeida ${ }^{1}$, \\ Antonio C. T. da Costa ${ }^{1} \&$ Gilberto O. Tomm ${ }^{2}$ \\ ${ }^{1}$ Universidade Estadual do Oeste do Paraná/Programa de Pós-Graduação em Agronomia. Marechal Cândido Rondon, PR, Brasil.E-mail:willian_agro@hotmail.com \\ (Corresponding author) - ORCID: 0000-0002-2642-5336; jose.júnior6@unioeste.br - ORCID: 0000-0002-4297-5530; ivonei.agronomia@hotmail.com - ORCID: \\ 0000-0003-4955-3258; brunohenrique.almeida@hotmail.com - ORCID: 0000-0003-3268-4147; antonio.unioeste@hotmail.com - ORCID:0000-0002-3369-9642 \\ ${ }^{2}$ Empresa Brasileira de Pesquisa Agropecuária/Centro Nacional de Pesquisa de Trigo. Passo Fundo, RS, Brasil. E-mail: gilberto.tomm@embrapa.br - ORCID: \\ 0000-0002-2300-1239
}

\begin{abstract}
Uneven maturation in canola is an important challenge for its management in regions subject to frost and high rainfall at the end of the cycle. In order to identify practices to maximize grain yield under these growing conditions, this work evaluated the effects of desiccation with herbicides at different phenological stages on Hyola 433, one of the most commonly used hybrids in Brazil. The experiment was conducted in a randomized block design with four repetitions in a $6 \times 4$ factorial scheme, with five herbicides: paraquat, diquat and ammonium glufosinate at dose of $400 \mathrm{~g}$ a.i. ha- ${ }^{-1}$, glyphosate at 1,440 $\mathrm{g}$ a.i. ha ${ }^{-1}$ and saflufenacil at $70 \mathrm{~g}$ a.i. ha ${ }^{-1}$, plus the control, at four phenological stages of silique maturation $\left(G_{2}, G_{3}, G_{4}\right.$ and $\left.G_{5}\right)$. Desiccation at $\mathrm{G}_{2}$ and $\mathrm{G}_{3}$ reduced the oil content and thousand-grain weight on average by $60 \%$, affecting directly grain yield. Desiccation at $\mathrm{G}_{4}$, regardless of herbicide, did not influence thousand-grain weight and oil content, but the use of diquat reduced canola yield by $187 \mathrm{~kg} \mathrm{ha}^{-1}$. In the desiccation at $\mathrm{G}_{5}$, none of the herbicides led to differences compared to the control for thousand-grain weight, yield and oil content, and it allowed harvest to be brought forward by five days. In general, the crop presents adequate responses to the desiccation with different herbicides at the phenological stages $G_{4}$ and $G_{5}$.
\end{abstract}

Key words: harvest antecipation, grain yield, oil content

\section{Desempenho agronômico de canola submetida à dessecação com herbicidas em diferentes estádios fenológicos da maturação}

RESUMO: A desuniformidade na maturação da canola constitui importante desafio para o manejo da cultura nas regiões sujeitas às geadas e/ou às elevadas precipitações no final do ciclo. Visando identificar práticas para maximizar o rendimento de grãos sob estas condições de cultivo, este trabalho avaliou os efeitos da dessecação com herbicidas em diferentes estádios fenológicos sobre Hyola 433, um dos híbridos mais empregados nas lavouras do Brasil. O experimento foi conduzido num delineamento de blocos casualizados, com quatro repetições, em esquema fatorial $6 \times 4$, sendo cinco herbicidas: paraquat, diquat e glufosinato de amônio na dose de 400 g i.a ha-1, glifosato com 1.440 g i.a ha-1 e saflufenacil dosado em 70 g i.a ha-1, mais a testemunha, em quatro estádios fenológicos da maturação das síliquas $\left(G_{2}, G_{3}, G_{4}\right.$ e $\left.G_{5}\right)$. A dessecação em $G_{2}$ e $G_{3}$ reduziu $60 \%$ em média o conteúdo de óleo e a massa de mil grãos, impactando diretamente no rendimento de grãos. A dessecação em $\mathrm{G}_{4}$, independentemente do herbicida, não influenciou a massa de mil grãos e o conteúdo de óleo; todavia, o uso de diquat reduziu a produtividade em $187 \mathrm{~kg} \mathrm{ha}^{-1}$. Na dessecação em $\mathrm{G}_{5}$, nenhum dos herbicidas determinou diferenças em relação à testemunha para massa de mil grãos, produtividade e teor de óleo e ainda permitiu uma antecipação da colheita em cinco dias. De um modo geral, a cultura apresenta respostas adequadas à dessecação com diferentes herbicidas nos estádios fenológicos $\mathrm{G}_{4}$ e $\mathrm{G}_{5}$.

Palavras-chave: antecipação da colheita, produtividade, teor de óleo 


\section{INTRODUCTION}

Canola crop (Brassica napus L.) is currently consolidated as an excellent option for agricultural diversification. Nonetheless, the natural dehiscence of siliques and long flowering period, with several layers, as well as the acropetal aspect of maturation, i.e., it occurs unevenly and upward from the base in the main stem and secondary branches, constitute an important challenge for the management of the crop in regions subject to frosts and high rainfall levels late in the cycle (Silva et al., 2011).

These factors increase the difficulty to define the beginning of harvest. The most used and efficient method to remove grains from the field is cutting and swathing, employing harvesters with special platforms, followed by collection and threshing. Another alternative is direct harvesting after herbicide application, aiming at standardization of silique maturation and fast drying of plants (Marchiori Júnior et al., 2002).

In Southern Brazil, results of research in this field are limited and information and definitions have been varied. Recent studies have tried to identify the best moment for crop desiccation. Pizolotto et al. (2016) observed that desiccation at $G_{5}$ (physiological maturity) with diquat and ammonium glufosinate reduced yield losses by $20 \%$ when compared to natural maturation of plants.

In Iran, Esfahani et al. (2012) reported that spring canola hybrids lost on average $6 \%$ of their moisture content when subjected to paraquat application at doses between 200 and $300 \mathrm{~g}$ a.i. ha ${ }^{-1}$ at the phenological stage $\mathrm{G}_{4}$ (early maturation), with about $40 \%$ of moisture, bringing harvest forward by 12 days, without negative effects on grain production and quality.

Nevertheless, Albrecht et al. (2013) found no interaction for variables such as thousand-grain weight and yield when paraquat was applied in the crop with grain moisture contents of 30 and $45 \%$, and concluded that canola maturation uniformity is influenced by factors such as genetic composition, edaphoclimatic conditions, crop management and even sowing period.

Desiccation with herbicides at phenological stages prior to physiological maturity directly interferes with the biological cycle of the plants, with probable influence on their agronomic variables. In this context, this study aimed to evaluate the agronomic performance of canola subjected to desiccation with herbicides at different phenological stages of maturation.

\section{Material And Methods}

The experiment was conducted in the field and under rainfed conditions, in the Western region of Paraná, Brazil, at $24^{\circ} 40^{\prime} \mathrm{S}$ latitude, $53^{\circ} 38^{\circ} \mathrm{W}$ longitude and $490 \mathrm{~m}$ altitude above the sea level, in the period from May 10 to August 30, 2016. The soil of the area is classified as Eutroferric Red Latosol, with clay texture (EMBRAPA, 2013). The meteorological data of temperature and rainfall were periodically collected along the experiment (Figure 1).

A randomized block design was used, with four replicates, in a $6 \times 4$ factorial scheme, which consisted of five herbicides (paraquat, diquat, ammonium glufosinate, glyphosate and saflufenacil) plus a control, at four phenological stages of the canola crop $\left(G_{2}\right.$ - first ten siliques with 2 to $4 \mathrm{~cm}, G_{3}$ first ten siliques longer than $4 \mathrm{~cm}, \mathrm{G}_{4}$ - first ten siliques at early maturation and $\mathrm{G}_{5}$ - dark-colored grains; physiological maturity) according to the phenological scale developed in France in 1992 by the Inter-professional Technical Center for Oilseeds and Hemp (CETIOM, 1992).

Plots were formed by six 5-m-long sowing rows spaced by $0.45 \mathrm{~m}$, characterizing one experimental unit of $13.5 \mathrm{~m}^{2}$ with evaluated area of $3.6 \mathrm{~m}^{2}$, composed of two 4-m-long central rows. The respective combinations occupied an area of $1,960 \mathrm{~m}^{2}$.

Fertilization at sowing was applied based on soil chemical analysis and expected yield of 2,000 kg ha-1, using $444 \mathrm{~kg} \mathrm{ha}^{-1}$ of the 06-18-10 formulation. When the crop reached the phenological stage $\mathrm{B}_{4}$ (four fully developed leaves), ammonium sulfate $\left(\left(\mathrm{NH}_{4}\right)_{2} \mathrm{SO}_{4}\right)$ was applied as topdressing at dose of $357 \mathrm{~kg} \mathrm{ha}^{-1}$ as recommended by Tomm et al. (2009).

Sowing was carried out on May 10, 2016, using a six-row sowing machine regulated to place 22 seeds per linear meter, at $1.5 \mathrm{~cm}$ depth. The canola hybrid Hyola 433 was used, which has a short cycle (120 to 150 days) with polygenic resistance

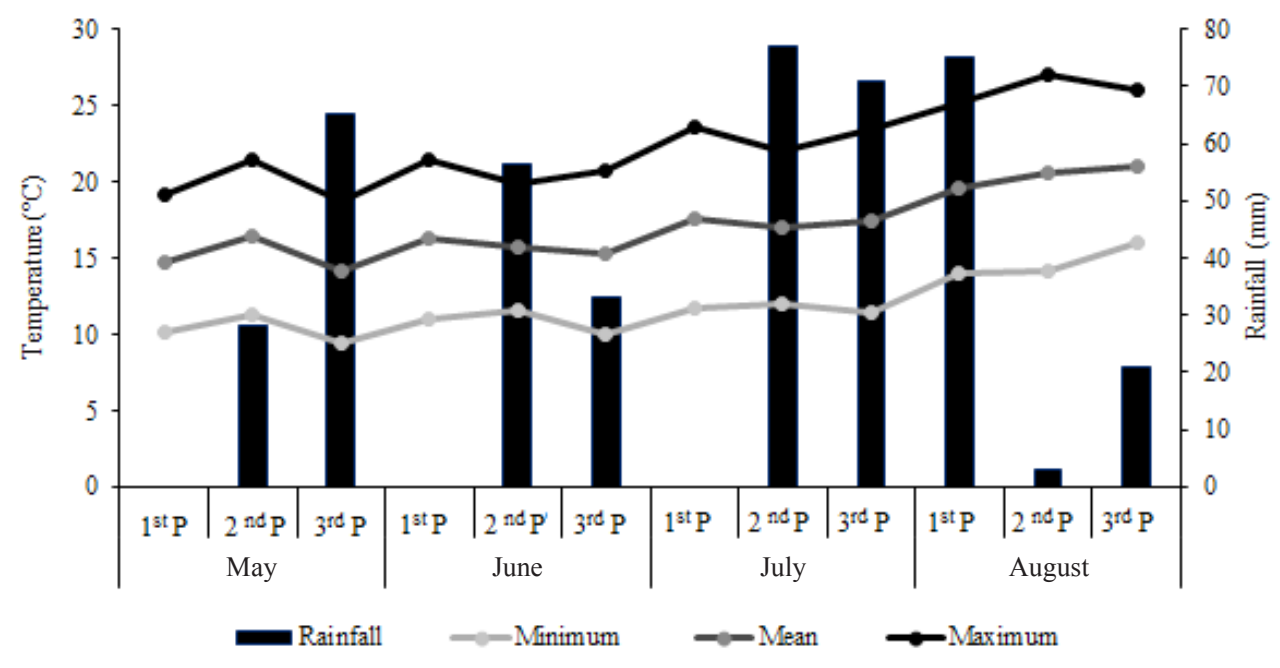

$1^{\text {st }} \mathrm{P}$ - First ten-day period $/ 2^{\text {nd }} \mathrm{P}$ - Second ten-day period $/ 3^{\text {rd }} \mathrm{P}$ - Third ten-day period

Figure 1. Meteorological data: minimum, mean and maximum temperatures $\left({ }^{\circ} \mathrm{C}\right)$ and rainfall (mm) collected by ten-day periods along the experiment 
to blackleg disease (Leptosphaeria maculans), registered in 2008 and indicated for high-fertility soils (Tomm et al., 2009).

Weed management was carried out at the rosette stage by manual weeding. In the period of elongation and flower bud formation, diamondback moth (Plutella xylostella) was controlled by the application of Teflubenzuron, a growthregulating insecticide which inhibits chitin synthesis, belonging to the chemical group of the Benzoylureas. Diseases were not observed along the development of canola plants.

Paraquat, diquat and ammonium glufosinate were applied at dose of $400 \mathrm{~g}$ a.i. ha ${ }^{-1}$, glyphosate at 1,440 g a.i. ha-1 and saflufenacil at $70 \mathrm{~g}$ a.i. ha ${ }^{-1}$. In all treatments the solution was mixed with $1 \%$ Nimbus paraffin mineral oil. Applications were carried out at 95, 105, 115 and 125 days after emergence (DAE), period when more than $50 \%$ of the plants characterized the phenological stages $G_{2}, G_{3}, G_{4}$ and $G_{5}$, respectively.

Applications were carried out using a $\mathrm{CO}_{2}$-pressurized backpack sprayer, equipped with one six-nozzle boom, with XR 110.02 nozzles spaced by $0.45 \mathrm{~m}$. The device worked at pressure of $30 \mathrm{psi}$, with service flow rate of $200 \mathrm{~L} \mathrm{ha}^{-1}$. The solutions were applied under the following conditions: temperatures from 24 to $28^{\circ} \mathrm{C}$, relative air humidity above $65 \%$ and wind speed below $7 \mathrm{~km} \mathrm{~h}^{-1}$.

Experimental units began to be harvested when the grains contained $20 \%$ moisture content, followed a period of sundrying for 10 days with subsequent threshing and cleaning of the grains. The time between desiccation at the respective phenological stages and harvest with $20 \%$ grain moisture varied according to the herbicides used and desiccation periods and was taken into account in the characterization of the parameter reduction in time to harvest.

The agronomic variables evaluated were plant height, number of siliques plant ${ }^{-1}$, number of grains silique ${ }^{-1}$, thousandgrain weight and grain yield, besides the number of days reduced in the time to harvest and grain oil content, which was estimated by the solvent extraction method, using Soxhlet extractor (Wennersten, 1992).

The data were subjected to Shapiro-Wilk normality test and variance analysis by $\mathrm{F}$ test at 0.05 probability level. Always when significance was observed, means of herbicides were compared by Tukey test at 0.05 probability level and regression analysis for days after emergence, using the statistical program Genes (Cruz, 2006).

\section{Results AND Discussion}

The agronomic variables plant height, number of siliques plant $^{-1}$ and number of grains silique ${ }^{-1}$ were not influenced by herbicide application at any phenological stage, with mean values of $1.28 \mathrm{~m}, 260$ siliques plant ${ }^{-1}$ and 24 grains silique ${ }^{-1}$, respectively.

Reduction in time to harvest (Figure 2) was discussed based on the mean values, instead of using a regression. Desiccation at $\mathrm{G}_{2}(95 \mathrm{DAE})$ and $\mathrm{G}_{3}(105 \mathrm{DAE})$ allowed harvest to be brought forward on average by 26 and 20 days, respectively. Although bringing harvest forward is of great interest economically and in the organization of property-level operations, the significant

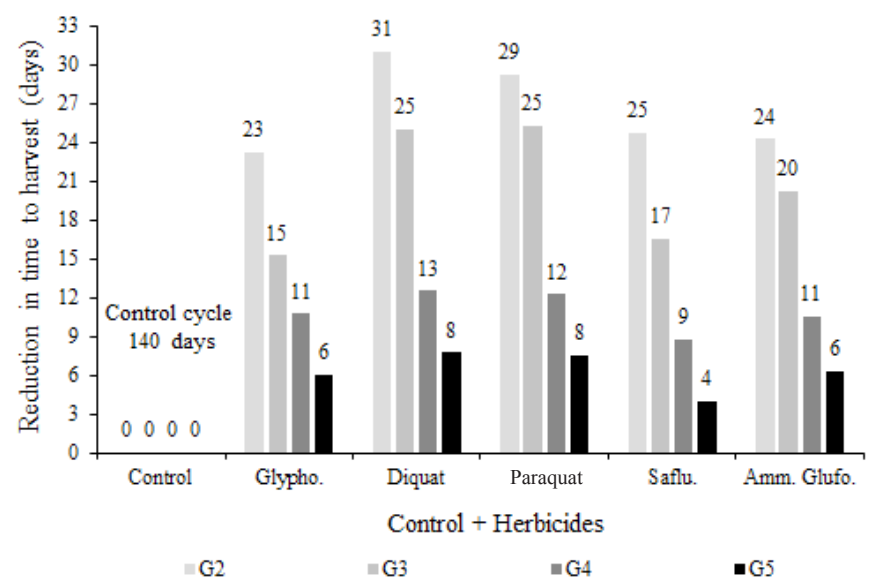

Figure 2. Reduction in time to harvest for the hybrid Hyola 433 , as a function of desiccation at different maturation stages $\left(G_{2}, G_{3}, G_{4}\right.$ and $G_{5}$, respectively at $95,105,115$ and 125 days after emergence)

losses in thousand-grain weight, grain yield and oil content indicate that desiccation should be carried out only after $\mathrm{G}_{3}$.

Desiccation at $G_{4}(115 \mathrm{DAE})$ and $\mathrm{G}_{5}(125 \mathrm{DAE})$ brought harvest forward on average by 11 and 6 days, respectively, compared to the control, without significant losses in the studied variables. These results corroborate those found by studies conducted in Canada (Darwent et al., 2000) and Iran (Esfahani et al., 2012), where canola desiccation close to the transition point from $G_{4}$ to $G_{5}$ brought harvest forward by 10 days.

The performance of each significant variable studied was compared to the control and, according to the analysis of variance (Table 1), there was significant interaction of desiccation periods with the herbicides.

The linear fits showed that thousand-grain weight did not exceed $2.0 \mathrm{~g}$ when desiccation was carried out using paraquat and diquat (Figures $3 \mathrm{E}$ and $\mathrm{F}$ ) at the phenological stages $\mathrm{G}_{2}$ and $\mathrm{G}_{3}$. Different values were observed in Figure 3A; under natural drying of the plants, the mean thousand-grain weight was $3.5 \mathrm{~g}$. It is worth highlighting that, under favorable conditions of climate, nutrition and health, this variable can easily surpass $4.0 \mathrm{~g}$ (Kaefer et al., 2014).

Paraquat and diquat, both contact and photosystem I-inhibiting herbicides, regardless of period of application, desiccated plants within an interval between 5 and 7 days, time significantly less than that required by systemic herbicides such as glyphosate (between 12 and 21 days). This rapid desiccation of the plant occurs due to the fact that these contact herbicides form superoxide radicals that disintegrate in hydrogen peroxide

Table 1. Summary of analysis of variance for the analysed variables as a function of desiccation with herbicides at different maturation periods of the hybrid Hyola 433

\begin{tabular}{lcccc}
\hline \multicolumn{1}{c}{$\begin{array}{c}\text { Source } \\
\text { of variation }\end{array}$} & \multicolumn{4}{c}{ Mean square } \\
\cline { 2 - 5 } & DF & TGW & GY & OC \\
Period & 3 & $15.25^{*}$ & $8804578.77^{*}$ & $3133.89^{\star}$ \\
Herbicide & 5 & $2.67^{*}$ & $1181438.84^{*}$ & $383.15^{*}$ \\
Period x Herbicide & 15 & $0.70^{*}$ & $410966.36^{*}$ & $131.54^{*}$ \\
Error & 69 & 0.05 & 5789.23 & 2.99 \\
CV (\%) & & 8.59 & 6.17 & 6.53 \\
Overall mean & & $2.68(\mathrm{~g})$ & $1232.24\left(\mathrm{~kg} \mathrm{ha}^{-1}\right)$ & $26.51(\%)$ \\
\hline
\end{tabular}

* Significant at $\mathrm{p} \leq 0.05$ by F test, CV (\%) - Coefficient of variation; TGW - Thousandgrain weight; GY - Grain yield; OC - Oil content in the grains 

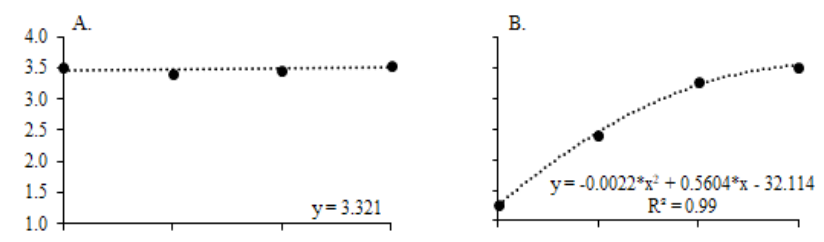

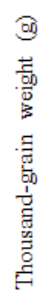
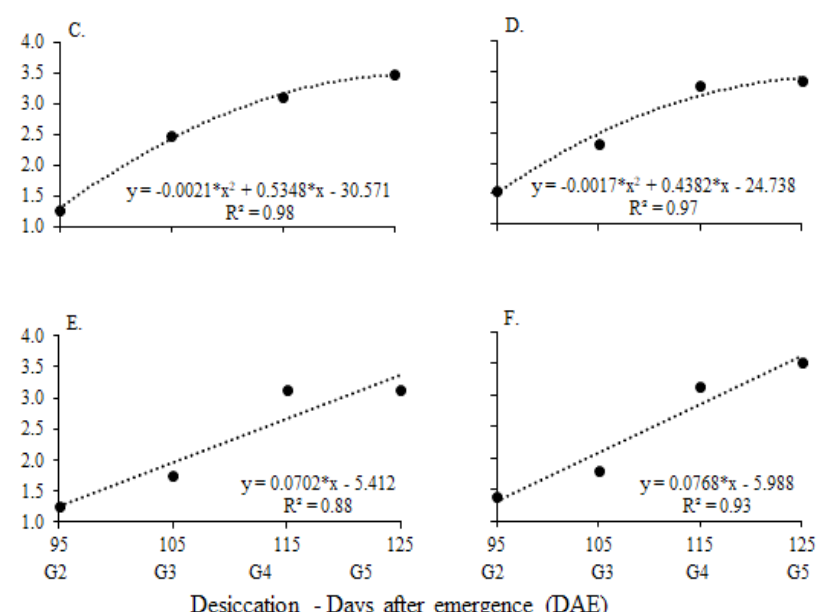

* significant at $\mathrm{p} \leq 0.05$ level by the $\mathrm{t}$-test

Figure 3. Thousand-grain weight of the canola hybrid Hyola 433 as a function of desiccation with herbicides at different days after emergence (DAE): control (A), ammonium glufosinate (B), saflufenacil (C), glyphosate (D), paraquat (E) and diquat (F)

$\left(\mathrm{H}_{2} \mathrm{O}_{2}\right)$, directly resulting in the degradation of cell membranes and accelerating the death of plant tissues (Costa et al., 2014).

The data of desiccation with ammonium glufosinate, saflufenacil and glyphosate (Figures 3B, C and D, respectively) fitted to a quadratic model in which the maximum point indicates which is the best moment to desiccate the crop with these herbicides. Considering this variable, such moment occurs in the transition from $G_{4}$ to $G_{5}$, i.e., in the interval adjusted between 120 and 125 DAE for the hybrid Hyola 433 under the conditions of this crop season and site. Marchiori Júnior et al. (2002) found that the best period for desiccation with systemic herbicides is the phenological stage $G_{5}$.

In order to cause phytotoxic effects, systemic herbicides need to be absorbed and translocated to specific regions of the plant, as observed in the present study, in which the full desiccation of the plants occurred between 12 and 21 days after application of the herbicides. Constantin et al. (2008) claimed that, as long as the plant has active photosynthetic tissues, the translocation of photoassimilates and dry matter accumulation continue to occur.

Based on the linear model, grain yield increased as a function of desiccation period, regardless of herbicide, so that desiccation at $G_{2}$ and $G_{3}$ reduced the mean yield by 1,464 and $1,087 \mathrm{~kg} \mathrm{ha}^{-1}$, respectively, compared to the control (Figures 4B, C, D, E and $\mathrm{F}$ ). These results indicate that biomass accumulation was interrupted by the effect of desiccation and that maturation was forced due to the fast intensification of water loss from tissues and grains which were still in the process of formation.

The desiccation with the systemics herbicides saflufenacil and glyphosate in $G_{2}$ and $G_{3}$ promoted a significant decrease in productivity in relation to the phenological stages $G_{4}$ and $\mathrm{G}_{5}$, which was not different between them (Figures $4 \mathrm{C}$ and $\mathrm{D}$ )
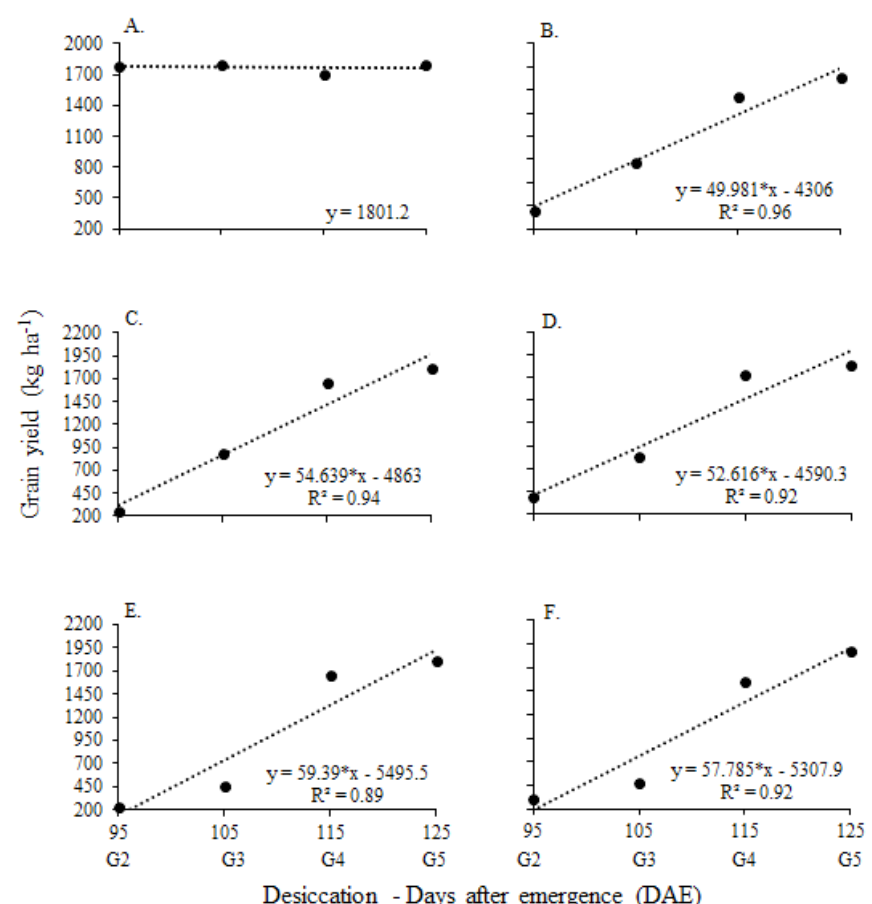

* significant at $\mathrm{p} \leq 0.05$ level by the $\mathrm{t}$-test

Figure 4. Variations in grain yield for the canola hybrid Hyola 433 as a function of desiccation with herbicides at days after emergence. control (A), ammonium glufosinate (B), saflufenacil (C), glyphosate (D), paraquat (E) and diquat (F)

and the control (Figure 4A). Different behavior was observed in the desiccation with paraquat and diquat (Figures $4 \mathrm{E}$ and $\mathrm{F}$ ), where the $G_{4}$ desiccation promoted a mean reduction of 157 and $317 \mathrm{~kg} \mathrm{ha}^{-1}$, compared to $\mathrm{G}_{5}$, respectively. These differences may be related to the effect of the herbicides and to the high degree of silica maturation.

Nunes et al. (2015) also observed that the use of ammonium glufosinate led to lower yield losses when compared to diquat in applications immediately before physiological maturity. Darwent et al. (1994) reported similar behavior in a study evaluating the agronomic yield of canola desiccated with glyphosate and ammonium glufosinate at phenological stages prior to $G_{5}$.

Understanding the phenotypic dynamics of canola plants is essential to make crop management effective. Although the plant reached maximum dry matter accumulation at the phenological stage $G_{4}$, it was in $G_{5}$ that the siliques of the lower and upper thirds of the branches had the greatest phenological balance, i.e., from that point plants lost water at higher rate and siliques from the base of the branches began the natural dehiscence process.

Rose et al. (2008) and Wang et al. (2011) found that the siliques from the base of the branches have greater availability of photoassimilates in comparison to those of the upper third, and the fact that canola has acropetal maturation is what generates the greatest problems at harvest. Clarke (1989) also states that during maturation the wall of siliques and the stems are the last sources of material for translocation and accumulation in the grains.

All herbicides drastically reduced grain oil content when desiccation was carried out at $G_{2}$ and $G_{3}$ (Figures $5 B, C, D$, $\mathrm{E}$ and $\mathrm{F}$ ). According to the fitted model, the reductions were on mean 48.7 and 75\%, respectively. Portella \& Tomm (2007) state that during maturation there is natural degradation of 
chlorophyll and premature desiccation of the plant, resulting in the reduction of oil accumulation in the grains and presence of toxic residues and chlorophyll, which depreciate the product and increase industrial costs for oil clarification.

Compared to the control (Figure 5A), desiccation at $\mathrm{G}_{5}$ with any of the herbicides did not affect the oil content (Figures $5 \mathrm{~B}$, C, D, E and F) and, although the desiccation at $\mathrm{G}_{4}$ reduced grain yield, it did not reduce grain oil contents. These results indicate that desiccation at $\mathrm{G}_{4}$ can be an alternative to be employed in cases where climate forecasts point to imminent high risks of losses due to strong winds, heavy rains and hailstorms, which may preclude harvesting operations and reduce grain yield and quality.
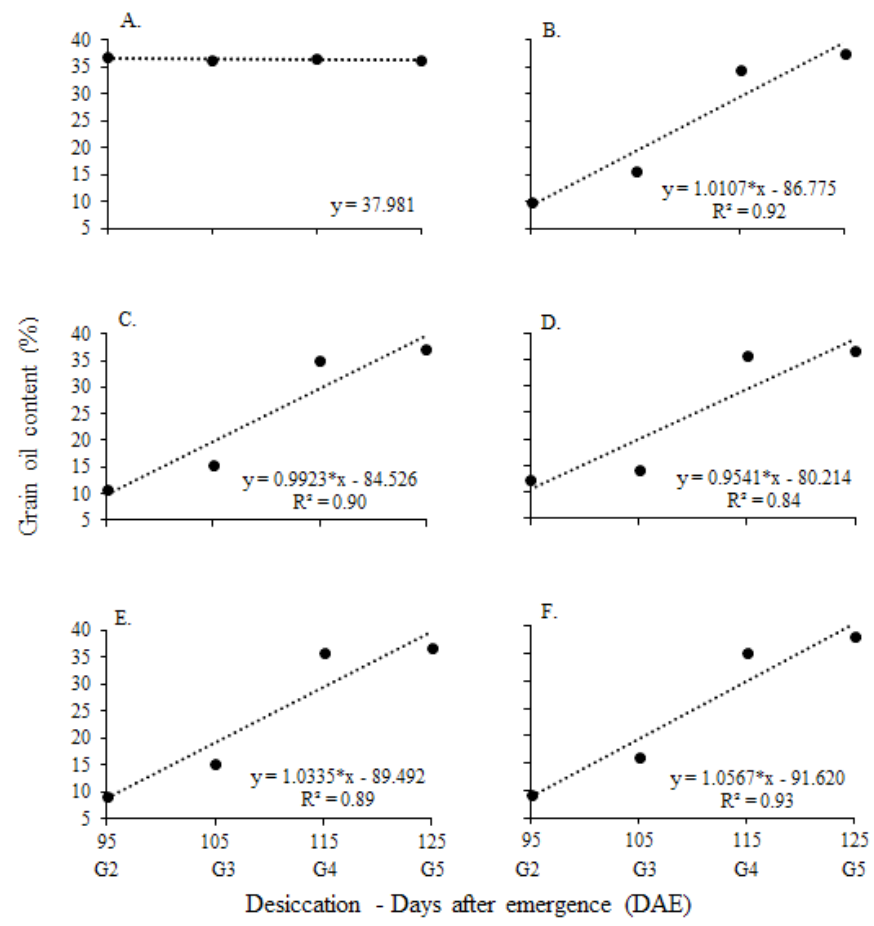

* significant at $\mathrm{p} \leq 0.05$ level by the t-test

Figure 5. Oil content in the canola hybrid Hyola 433 as a function of desiccation of herbicides at days after emergence: control (A), ammonium glufosinate (B), saflufenacil (C), glyphosate (D), paraquat $(\mathrm{E})$ and diquat $(\mathrm{F})$

\section{Conclusions}

1. It is not recommended to desiccate canola at the phenological stages $G_{2}$ (first ten siliques with 2 to $4 \mathrm{~cm}$ ) and $G_{3}$ (first ten siliques longer than $4 \mathrm{~cm}$ ) using the studied herbicides.

2 . The agronomic variables thousand-grain weight and oil content positively respond to desiccation at $\mathrm{G}_{4}$ (first ten siliques at early maturation) and $\mathrm{G}_{5}$ (dark-colored grains; physiological maturity), regardless of herbicide.

3. This study suggests the phenological stage $G_{5}$ as the most indicated to desiccate the crop.

\section{Literature Cited}

Albrecht, L. P.; Krenchinski, F. H.; Placido, H. F.; Bomm, M. A. R.; Kunz, V. L.; Korber, A. H. C.; Bieler, R. R. Canola desiccation at different stages of pods maturation. Revista Brasileira de Herbicidas, v.12, p.143-150, 2013. https://doi.org/10.7824/rbh.v12i2.188
CETIOM - Centre Technique Interprofessionnel des Oléagineux Métropolitains. La cultura du colza d'hiver: Guide cultural 1991/1992. Paris: CETIOM, 1992. 33p.

Clarke, J. M. Intra-plant variation in number of seeds per pod and seed weight in Brassica napus 'Tower'. Canadian Journal of Plant Science, v.59, p.959-962, 1989. https://doi.org/10.4141/cjps79-152

Constantin, J.; Machado, M. H.; Cavalieri, S. D.; Oliveira Junior, R. S.; Rios, F. A.; Roso, A. C. Influência do glyphosate na dessecação de capim-braquiária e sobre o desenvolvimento inicial da cultura do milho. Planta Daninha, v.26, p.627-636, 2008. https://doi. org/10.1590/S0100-83582008000300019

Costa, N. V.; Andrade, D. C. de; Dourado, R. F.; Pavan, G. C.; Costa, A. C. P. R. da. Dessecação da Brachiaria ruziziensis com paraquat antes da semeadura da soja. Revista Brasileira de Herbicidas, v.13, p.235-244, 2014. https://doi.org/10.7824/rbh.v13i3.277

Cruz, C. D. Programa Genes: Aplicativo computacional em genética e estatística. Viçosa: Editora UFV, 2006. 442p.

Darwent, A. L.; Kirkland, K. J.; Baig, M. N.; Lefkovitch, L. P. Preharvest applications of glyphosate for Canada thistle (Cirsium arvense). Weed Technology, v.8, p.477-482, 1994. https://doi.org/10.1017/ S0890037X00039543

Darwent, A. L.; Kirkland, K. J.; Townley-Smith, L.; Harker, K. N. Cessna, A. J. Effect of preharvest applications of glyphosate on the drying, yield and quality of canola. Canadian Journal of Plant Science, v.80, p.433-439, 2000. https://doi.org/10.4141/P99-063

EMBRAPA - Empresa Brasileira de Pesquisa Agropecuária. Sistema brasileiro de classificação de solos. Brasília: Embrapa Informação Tecnológica, 2013. 343p.

Esfahani, M.; Fardi, M.; Asghari, J.; Rabiei, M.; Samizadeh, H. Effects of pre-harvest application of parquat on grain moisture reduction, grain yield and quality of rapeseed (Brassica napus L.) cultivars. Caspian Journal of Environmental Science, v.10, p.75-82, 2012.

Kaefer, J. E.; Guimarães, F. V.; Richart, A.; Tomm, G. O.; Müller, A. L. Produtividade de grãos e componentes de produção da canola de acordo com fontes e doses de nitrogênio. Pesquisa Agropecuária Brasileira, v.49, p.273-280, 2014. https://doi.org/10.1590/S0100204X2014000400005

Marchiori Júnior, O.; Inoue, M. H.; Braccini, A. L.; Oliveira Júnior, R. S.; Avila, M. R.; Lawder, M.; Contantini, J. Qualidade e produtividade de sementes de canola (Brassica napus) após aplicação de dessecantes em pré-colheita. Planta Daninha, v.20, p.253-261, 2002. https://doi.org/10.1590/S0100-83582002000200012

Nunes, A. L.; Ascari, J.; Pereira, L.; Sossmeier, S. G.; Bispo, N. B. Pod sealant and canola harvest methods for pod shattering mitigation. Australian Journal of Crop Science, v.9, p.865-869, 2015.

Pizolotto, C. A.; Boller, W.; Lângaro, N. C.; Tomm, G. O. Dessecação em pré-colheita e corte-enleiramento combinados a um adesionante como estratégia de manejo na redução de perdas de grãos em canola. Scientia Agraria Paranaensis, v.15, p.265-271, 2016. https://doi.org/10.18188/1983-1471/sap.v15n3p265-271

Portella, J. A.; Tomm, G. O. Enleiramento e colheita de canola. Passo Fundo: Embrapa Trigo, 2007. 11p. Documentos, 89

Rose, T. J.; Rengel, Z.; Ma, Q.; Bowden, J. W. Post-flowering supply of $\mathrm{P}$, but not $\mathrm{K}$, is required for maximum canola seed yields. European Journal of Agronomy, v.28, p.371-379, 2008. https:// doi.org/10.1016/j.eja.2007.11.003 
Silva, J. A. G. da; Motta, M. B. da; Winch, J. A.; Crestani, M.; Fernandes, S. B. V.; Berto, J. L.; Gaviraghi, F.; Martins, J. A. K.; Wagner, J. F.; Valentini, A. P. F.; Zambonato, F. Dessecação em pré-colheita como estratégia de manejo na redução de perdas por fatores de ambiente em canola. Revista Brasileira de Agrociência, v.17, p.15-24, 2011.

Tomm, G. O.; Wiethölter, S.; Dalmago, G. A.; Santos, H. P. dos. Tecnologia para produção de canola no Rio Grande do Sul. Passo Fundo: Embrapa Trigo, 2009. 39p. Documentos, 113
Wang, Y.; Sun, S.; Liu, B.; Wang, H.; Deng, J.; Liao, Y.; Wang, Q.; Cheng, F.; Wang, X.; Wu, J. A sequence-based genetic linkage map as a reference for Brassica rapa pseudochromosome assembly. BMC Genomics, v.12, p.1-10, 2011. https://doi.org/10.1186/14712164-12-239

Wennersten, R. Extraction of organic compounds. In: Ydberg, J.; Musikas, C.; Choppin, G. R. Principles and practices of solvent extraction. New York: Marcel Dekker, 1992. Chap.9, p.115-356. 